\title{
Miller-Fischer syndrome after etanercept
}

\author{
Elena Grebenciucova1, John H. Pula² \\ ${ }^{1}$ Department of Neurology, University of Pennsylvania, Philadelphia, PA 19019, USA. \\ ${ }^{2}$ Department of Neurology, HealthSystem, NorthShore University, Evanston, IL 60069, USA.
}

Correspondence to: Dr. Elena Grebenciucova, Department of Neurology, University of Pennsylvania, Philadelphia, PA 19019, USA. E-mail: Elena.grebenciucova@uphs.upenn.edu

How to cite this article: Grebenciucova E, Pula JH. Miller-Fischer syndrome after etanercept. Neuroimmunol Neuroinflammation 2017;4:93-5.

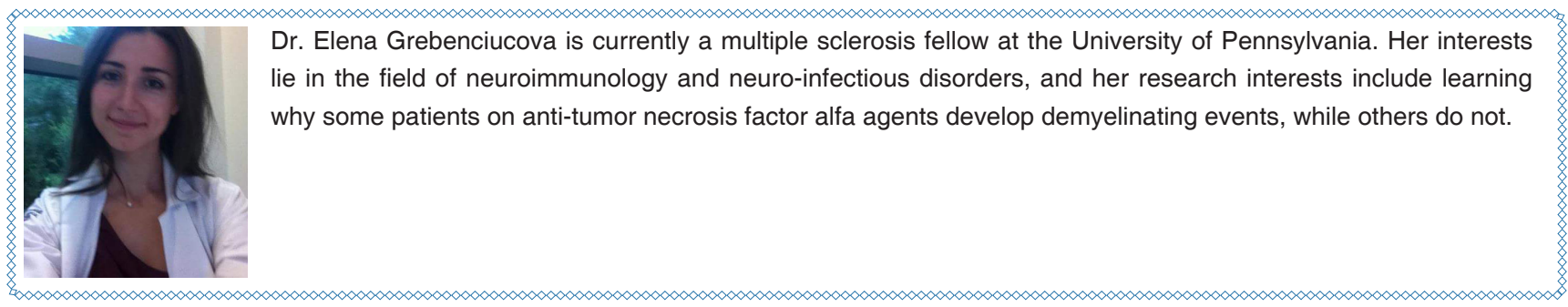

Article history:

Received: 22-11-2016

Accepted: 24-04-2017

Published: 23-05-2017

Key words:

Miller-Fischer syndrome,

demyelination,

anti-TNF $\alpha$ agent,

etanercept

\section{ABSTRACT}

The authors describe a case of Miller-Fischer syndrome, a rare demyelinating syndrome, preceded by a viral prodrome and three doses of etanercept, an anti-tumor necrosis factor $\alpha$ (anti-TNF $\alpha)$ agent. Anti-TNF $\alpha$ agents are associated with an induction of episodes of demyelination and may unmask multiple sclerosis in those who are immunogenetically predisposed.

\section{INTRODUCTION}

Miller-Fischer syndrome (MFS) is a rare selflimiting demyelinating disorder that is considered to be a variant of Guillain-Barre syndrome (GBS). MFS typically affects cranial nerves first and then descends, classically resulting in a clinical triad of ophthalmoplegia, areflexia, and ataxia. ${ }^{[1]}$ An antibody against the ganglioside Q1b (GQ1b) is $90 \%$ specific and $85-90 \%$ sensitive. ${ }^{[2]}$ Cases of demyelination, both central and peripheral, have been described in patients treated with anti-tumor necrosis factor $\alpha$ (anti$\mathrm{TNF} \alpha$ ) agents. This case describes a patient with MFS preceded by both a viral illness and the use of the antiTNF $\alpha$ agent etanercept. 


\section{CASE REPORT}

A 54-year-old male with history of psoriatic arthritis presented for an evaluation of the acute onset of ocular pain and double vision. He had recently started Etanercept, an anti-TNF $\alpha$ antibody. Five days after the 1st infusion, he developed rhinitis and a cough, which resolved in several days. He proceeded with his weekly 2 nd and 3rd infusions, but 2 days after the 3 rd infusion he developed blurred vision in the right eye and pain with eye movement. Two days later, he developed double vision and ocular pain when attempting upgaze, followed by headache and pain with eye movement in all directions.

Three days after the onset of his symptoms, he was evaluated by an ophthalmologist who noted incomplete adduction of the left eye on far right gaze. Five days later, a neuro-ophthalmologic examination showed bilateral eye adduction weakness with an upgaze palsy, along with a mild left eye ptosis and miosis. Direct and consensual reaction of pupils was intact. There was no afferent pupillary defect or disc edema.

The rest of the neurological examination was significant for areflexia, while cerebellar exam was normal.

A contrast-enhanced magnetic resonance imaging (MRI) of the brain was performed 3 days after onset of symptoms, and no midbrain or pontine lesions were noted. There was no optic nerve enhancement noted on orbital imaging. Acetyl-choline receptor and muscle specific kinase antibodies were both negative.

He underwent another MRI two weeks after the onset of symptoms, and both MRI of the brain and orbits with and without contrast were again unremarkable. At this point, MFS was considered, and a GQ1b antibody was tested, which was positive with a titer of $1: 12,800$. One month after the onset of his symptoms, he was essentially asymptomatic, and his neurologic examination normalized, other than residual areflexia.

\section{DISCUSSION}

MFS is a rare self-limiting demyelinating syndrome that is considered to be a variant of GBS. Annual incidence is estimated to be one case per million. ${ }^{[3]} \mathrm{A}$ clinical triad of ophthalmoplegia, arreflexia, and ataxia is the classic presentation.

An antibody to the neuronal GQ1b (or in some cases GT1a) is highly sensitive and specific for the diagnosis of MFS. About $60 \%$ of cases are preceded by a viral or in some cases bacterial illness. The disease occurs more commonly in males than females and is treated with intravenous immunoglobulins or plasmaphoresis, although according to the Cochrane review, patients who were not treated with either therapy had similar outcomes at 6 months. ${ }^{[4]}$ However, the data are difficult to interpret due to the low incidence of the disease and consequent lack of randomized placebocontrolled trials. In most cases, the course of the disease is self-limiting and the outcomes are favorable. In our patient, the onset of MFS was preceded by a viral prodrome, but also occurred in the context of an anti-TNF $\alpha$ agent.

The use of anti TNF $\alpha$ agents in the treatment of various rheumatological disorders such as sarcoidosis, rheumatoid arthritis, and psoriasis has been increasingly recognized as causal to cases of demyelination, some of which remain monophasic, with a minority transitioning into multiple sclerosis. Due to their anti-inflammatory activity, anti-TNF $\alpha$ agents have been previously investigated in multiple sclerosis, however a randomized placebo-controlled trial of anti-TNF $\alpha$ agent in multiple sclerosis showed worsening of the disease activity in the anti-TNF $\alpha$ group. ${ }^{[5]}$

TNF $\alpha$ is a cytokine that binds to TNF receptor 1 (TNFR1) or 2 (TNFR2). TNFR1 binding results in the inflammatory effects of TNF, while TNFR2 binding contributes to the maintenance of immune tolerance. TNF $\alpha$ binding to TNFR2 in conjunction with IL-2 result in $T$ regulatory cells proliferation, increase in forkhead box P3 expression and an increased immunosuppressive activity. ${ }^{[6]}$ Thus, inhibiting TNF can alter the balance between the effector and regulatory $T$ cells, potentially leading to dysregulation of immune tolerance and allowing an increased activity of autoreactive $T$ cells. As a result of this imbalance, humoral immunity can be further activated resulting in the auto-reactive antibody generation. ${ }^{[7]}$ It is possible that in the immunogenetically susceptible people, the use of anti-TNF $\alpha$ agents may result in an episode of demyelination or unmask the predilection for multiple sclerosis. The detailed pathophysiological mechanism has not been fully elucidated.

Cases of GBS have also been associated with the use of anti-TNF $\alpha$ agents.

Besides our case, a review of the literature uncovered three prior cases of MFS in association with the use of anti-TNF $\alpha$ blockers [Table 1]. ${ }^{[8-10]}$ The underlying mechanism of MFS in association with anti-TNF $\alpha$ blockers is likewise unclear. In our case, given a preceding viral illness, it becomes of interest whether the anti-TNF $\alpha$ agent further contributed to the development of the syndrome or if it had any 
Table 1: Literature cases of MFS in association with anti-TNF $\alpha$ agents

\begin{tabular}{|c|c|c|c|c|c|c|c|c|}
\hline Reference & Patient & $\begin{array}{l}\text { Anti TNF } \\
\text { agent }\end{array}$ & $\begin{array}{l}\text { Underlying } \\
\text { condition }\end{array}$ & $\begin{array}{l}\text { Duration of } \\
\text { treatment }\end{array}$ & $\begin{array}{l}\text { Symptoms at } \\
\text { onset }\end{array}$ & $\begin{array}{l}\text { GQ1b } \\
\text { titre }\end{array}$ & Treatment & Outcomes \\
\hline $\begin{array}{l}\text { Kurmann } \\
\text { et al. } .^{[9]}\end{array}$ & $\begin{array}{l}77 \text { years/ } \\
\text { female }\end{array}$ & Adalimumab & $\begin{array}{l}\text { Rheumatoid } \\
\text { arthritis }\end{array}$ & 2 infusions & $\begin{array}{l}\text { Ataxia, areflexia, } \\
\text { nystagmus }\end{array}$ & Negative & $\begin{array}{l}\text { Steroids/ } \\
\text { azathioprine }\end{array}$ & $\begin{array}{l}\text { Gradual } \\
\text { recovery over } \\
1 \text { year }\end{array}$ \\
\hline $\begin{array}{l}\text { Shin } \\
\text { et al. }{ }^{[8]}\end{array}$ & $\begin{array}{l}56 \text { years/ } \\
\text { male }\end{array}$ & Infliximab & $\begin{array}{l}\text { Rheumatoid } \\
\text { arthritis }\end{array}$ & 10 infusions & $\begin{array}{l}\text { Ataxia, } \\
\text { nystagmus }\end{array}$ & $<1: 100$ & $\begin{array}{l}\text { Steroids/ } \\
\text { IVIG }\end{array}$ & $\begin{array}{l}\text { Independent } \\
\text { ambulation at } \\
6 \text { months }\end{array}$ \\
\hline $\begin{array}{l}\text { Ratnarajan } \\
\text { et al } l^{[10]}\end{array}$ & $\begin{array}{l}43 \text { years/ } \\
\text { female }\end{array}$ & Infliximab & $\begin{array}{l}\text { Ulcerative } \\
\text { colitis }\end{array}$ & 2 infusions & Ophthalmoplegia & $1: 6,400$ & $\begin{array}{l}\text { No } \\
\text { treatment }\end{array}$ & $\begin{array}{l}\text { Full resolution } \\
\text { at } 10 \text { weeks }\end{array}$ \\
\hline Our patient & $\begin{array}{l}56 \text { years/ } \\
\text { male }\end{array}$ & Etanercept & $\begin{array}{l}\text { Psoriatic } \\
\text { arthritis }\end{array}$ & 3 infusions & $\begin{array}{l}\text { Ophthalmoplegia, } \\
\text { areflexia }\end{array}$ & $1: 128,000$ & $\begin{array}{l}\text { No } \\
\text { treatment }\end{array}$ & $\begin{array}{l}\text { Full recovery } \\
1 \text { month }\end{array}$ \\
\hline
\end{tabular}

MFS: Miller-Fischer syndrome; TNF: tumor necrosis factor; GQ1b: ganglioside Q1b; IVIG: intravenous immunogloblin

contributing effect on the course or severity of the disease.

This case illustrates the importance of considering MFS in patients presenting with ophthalmoplegia (even without ataxia) during use of an anti-TNF $\alpha$ agent. Further studies are necessary to understand the pathophysiological mechanisms of the aberrant immune responses leading to MFS, and the immunogenotypes of patients that may be at higher risk for immune dysregulation.

\section{Authors' contributions}

Analyzed the data and drafted the manuscript: E. Grebenciucova, J.H. Pula

\section{Financial support and sponsorship \\ None.}

\section{Conflicts of interest}

There are no conflicts of interest.

\section{Patient consent}

According to the requirements of the affiliation, this case report does not require patient consent.

\section{Ethics approval}

According to the requirements of the affiliation, this case report does not require ethics approval.

\section{REFERENCES}

1. Fisher M. An unusual variant of acute idiopathic polyneuritis (syndrome of ophtalmoplegia ataxia and areflexia). $N$ Eng $J$ Med 1956;255:57-65.

2. Nishimoto Y, Odaka M, Hirata K, Yuki N. Usefulness of anti-GQ1b IgG antibody testing in Fisher syndrome compared with cerebrospinal fluid examination. J Neuroimmunol 2004;148:200-5.

3. Arányi Z, Kovács T, Sipos I, Bereczki D. Miller Fisher syndrome: brief overview and update with a focus on electrophysiological findings. Eur J Neurol 2012;19:15-20.

4. Overell JR, Hsieh ST, Odaka M, Yuki N, Willison HJ. Treatment for Fisher syndrome, Bickerstaff's brainstem encephalitis and related disorders. Cochrane Database Syst Rev 2007;24:CD004761.

5. TNF neutralization in MS: results of a randomized, placebo-controlled multicenter study. The Lenercept Multiple Sclerosis Study Group and The University of British Columbia MS/MRI Analysis Group. Neurology 1999;53:457-65.

6. Chen X, Oppenheim JJ. TNF-alpha: an activator of CD4+FoxP3+TNFR2+ regulatory $\mathrm{T}$ cells. Curr Dir Autoimmun 2010;11:119-34

7. Robinson WH, Genovese MC, Moreland LW. Demyelinating and neurologic events reported in association with tumor necrosis factor alpha antagonism: by what mechanisms could tumor necrosis factor alpha antagonists improve rheumatoid arthritis but exacerbate multiple sclerosis? Arthritis Rheum 2001;44:1977-83.

8. Shin IS, Baer AN, Kwon HJ, Papadopoulos EJ, Siegel JN. GuillainBarré and Miller Fisher syndromes occurring with tumor necrosis factor alpha antagonist therapy. Arthritis Rheum 2006;54:1429-34.

9. Kurmann PT, Van Linthoudt D, So AK. Miller-Fisher syndrome in a patient with rheumatoid arthritis treated with adalimumab. Clin Rheumatol 2009;28:93-4.

10. Ratnarajan G, Thompson A, Dodridge C, Parry A, Elston J. Novel variant of miller fisher syndrome occurring with tumor necrosis factor $\alpha$ antagonist therapy. JAMA Neurol 2015;72:1377-8. 